\title{
Dieulafoy's lesion discovered after laparoscopic sleeve gastrectomy
}

\author{
Shinban Liu, Michael Nicoara, Nicholas Morin, George Ferzli
}

General Surgery, NYU Langone Medical Center, Brooklyn, New York, USA

\section{Correspondence to} Dr Shinban Liu, shinban.liu@nyumc.org

$S L$ and $M N$ contributed equally.

Accepted 30 October 2018

\section{DESCRIPTION}

A 51-year-old woman with a medical history significant for coronary artery disease, asthma, type 2 diabetes mellitus, obstructive sleep apnoea and body mass index (BMI) of $58 \mathrm{~kg} / \mathrm{m}^{2}$ underwent an uncomplicated laparoscopic sleeve gastrectomy. She tolerated the procedure well and was discharged home postoperative day 1 on a clear liquid diet per institutional guidelines. The following day, she presented to the emergency room with complaints of multiple episodes of bloody emesis. Her vitals on arrival were significant for tachycardia (129 bpm) and hypotension (96/57 mm Hg). Laboratory values demonstrated a drop in her haemoglobin and haematocrit $(10.3 \mathrm{~g} / \mathrm{dL}$ and $29.7 \%$ to $7.6 \mathrm{~g} / \mathrm{dL}$ and $23.3 \%$, respectively). She was immediately started on resuscitative fluids and transfused 2 units of packed red blood cells. Due to her recent surgery and clinical state, the decision was made to forgo imaging and proceed to oesophagogastroduodenoscopy (OGD) as it would be diagnostic and interventional. EGD demonstrated clotted blood along the entire oesophagus, an intact staple line and a large exposed vessel along the lesser curve of the stomach with no surrounding ulceration and active bleeding consistent with Dieulafoy's lesion (figure 1). Two endoclips were applied with successful haemostasis (figure 2). After the EGD, the patient remained haemodynamically stable with serial blood work and was discharged home after resuming diet.

A Dieulafoy's lesion is a dilated submucosal artery most commonly found in the proximal stomach along the lesser curvature that fails to undergo normal branching. ${ }^{1}$ Similar to this patient,

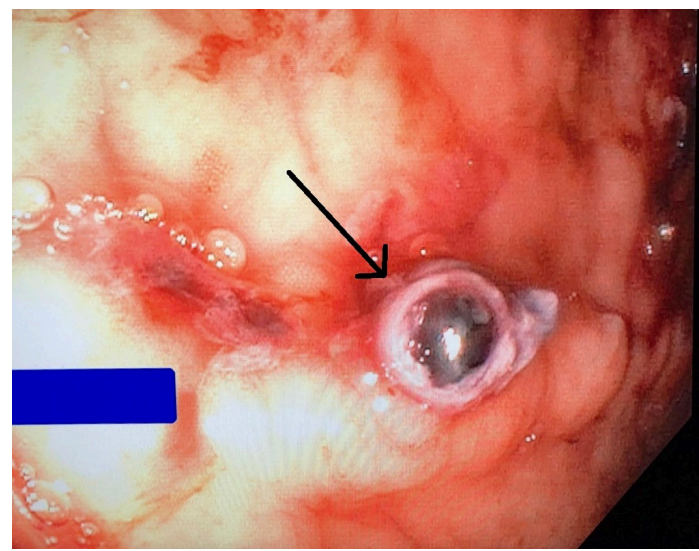

Figure 1 Oesophagogastroduodenoscopy demonstrating a large dilated and exposed vessel along the lesser curvature of the stomach with no surrounding ulceration and active bleeding consistent with Dieulafoy's lesion. The arrow indicates the Dieulafoy's lesion.

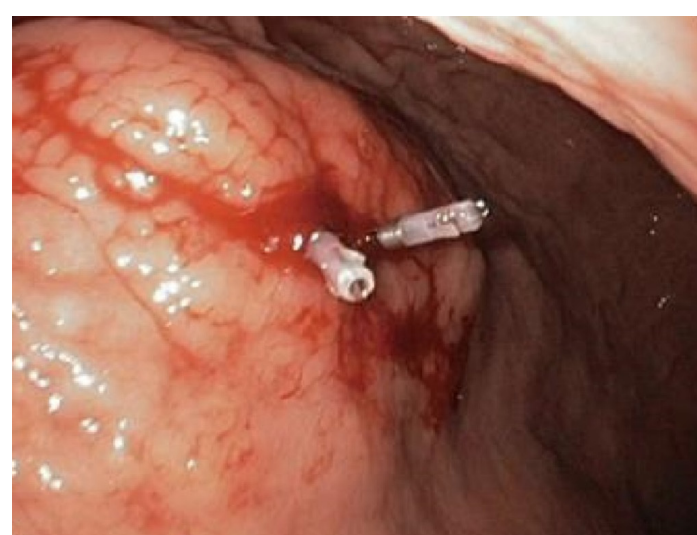

Figure 2 Application of endoclips to exposed vessel with successful haemostasis.

bleeding from these lesions tend to be spontaneous and are characteristically absent of surrounding primary ulceration. Episodes tend to be self-limited, however, bleeding is typically recurrent and may be life threatening. Endoscopy is the treatment of choice and thermal coagulation is considered the standard first-line intervention despite rebleeding rates as high as 50\%. Recent studies have suggested the use of endoclips or epinephrine injection therapy rather than thermal coagulation as it may have equal efficacy and decreased recurrence. ${ }^{2}$ While current American bariatric guidelines recommend preoperative endoscopy on patients with concern for gastric pathology, it is unclear whether these lesions would be effectively detected or if endoscopy would alter the course of management. ${ }^{3}$

\section{Learning points}

- Dieulafoy's lesions are dilated submucosal arteries that spontaneously bleed without primary ulceration.

- Endoscopy is the procedure of choice to diagnose and intervene on these lesions.

- Haemoclipping and epinephrine injection may have decreased bleed recurrence versus thermal coagulation.

Contributors SL, MN, NM and GF contributed equally to the drafting and editing of this manuscript.

Funding The authors have not declared a specific grant for this research from any funding agency in the public, commercial or not-for-profit sectors.

Competing interests None declared.

Patient consent Obtained. 
Provenance and peer review Not commissioned; externally peer reviewed.

\section{REFERENCES}

1 Lee YT, Walmsley RS, Leong RW, et al. Dieulafoy's lesion. Gastrointest Endosc 2003;58:236-43.
2 Chung IK, Kim EJ, Lee MS, et al. Bleeding Dieulafoy's lesions and the choice of endoscopic method: comparing the hemostatic efficacy of mechanical and injection methods. Gastrointest Endosc 2000;52:721-4.

3 SAGES Guidelines Committee. SAGES guideline for clinical application of laparoscopic bariatric surgery. Surg Endosc 2008;22:2281-300.

Copyright 2018 BMJ Publishing Group. All rights reserved. For permission to reuse any of this content visit https://www.bmj.com/company/products-services/rights-and-licensing/permissions/

BMJ Case Report Fellows may re-use this article for personal use and teaching without any further permission.

Become a Fellow of BMJ Case Reports today and you can:

- Submit as many cases as you like

- Enjoy fast sympathetic peer review and rapid publication of accepted articles

- Access all the published articles

- Re-use any of the published material for personal use and teaching without further permission

For information on Institutional Fellowships contact consortiasales@bmjgroup.com

Visit casereports.bmj.com for more articles like this and to become a Fellow 